\title{
ANALYSIS OF INVESTMENTS IN THE MODERNIZATION OF RAILWAY LINES AS PART OF RAIL TRANSPORT MANAGEMENT
}

\author{
Dorota GAWROŃSKA \\ Silesian University of Technology, Faculty of Organization and Management, Zabrze; \\ dorota.gawronska@polsl.pl, ORCID: 0000-0001-8192-0789
}

\section{Introduction}

Poland's accession to the EU gave a strong impetus to the country's economic development, including logistics in a broad sense, taking into account the supply chain: raw material supplier - producer - trader - customer. Railway transport plays a significant role because of the mass and volume of transit. In addition to the transportation of goods, rail transport plays a vital role in the transport of passengers, where, in addition to striving for European Union standards, it also aims to eliminate speed limits and direct the modernization of lines to high-speed lines, making railways a strong competitor for road transport.

The modernization of railway lines is based on the focus on changes. They can be associated, e.g., with plans to increase speed on given sections:

1. Recreation of the railway lines with a maximum speed of $120 \mathrm{~km} / \mathrm{h}$ and elimination of speed limit points.

2. Adaptation of the rail lines to a maximum speed of $160 \mathrm{~km} / \mathrm{h}$.

3. Adjustment of the lines to a maximum speed of $200 \mathrm{~km} / \mathrm{h}$.

Or they can concern different methods of train traffic control (SRK):

1. Telephone announcement.

2. Semi-automatic line blockade.

3. ECTS Level 1 system.

4. ECTS Level 2 system.

5. ECTS Level 3 system.

Modernizing the railway lines, regardless of the purpose, can be based on the criteria described in the next section. 


\section{Criteria for assessing railway lines}

The development of rail transport is a result of many factors, such as safety, environmental protection, costs, and profits of investment implementation or the use of current resources (Jacyna, 2001). The modernization efficiency is affected by many aspects, which is why the analysis of investments in rail infrastructure should be multicriterial. The following are the criteria for assessing railway lines divided into objectives (Jacyna, Wasiak, 2008; Matusik, 2017):

1. Social objective:

- increased safety (point or \%),

- impact of modernization on regional development (\%),

- ease of project implementation (point),

- increasing the share of rail transport in total transport in a given transport relation $(\%)$,

- $\quad$ reduction of travel time on a given section of the railway line (min) (weighted arithmetical mean for individual train categories),

- time availability of rail connections.

2. Technical:

- level of investment implementation ease (\% or point),

- throughput of a given section of a railway line (par poc./h),

- increasing train speed $(\mathrm{km} / \mathrm{h})$,

- for freight transport - the permissible pressure level of axle wagons on the track.

3. Environmental (due to environmental protection):

- reduction (decrease) of external costs by taking over passengers from road transport,

- noise reduction (emission) $(\mathrm{dB})$,

- decrease (level, probability) of number of accidents involving animals (pcs),

- degree (reduction) of impact on protected areas (\%),

- occupancy of the area by infrastructure (\%),

- $\quad$ water pollution $(\%)$.

4. Economic:

- profit from sharing infrastructure $(\mathrm{mln})$,

- costs of using railway infrastructure $(\mathrm{mln})$,

- expenditure on modernisation ( $\mathrm{mln})$,

- internal rate of return IRR,

- the share of railway infrastructure in all transport traffic (\%). 
Because the values of the assessment of some criteria are the result of the investor's analysis, assumptions, and assessment, the algorithm assumes the possibility of uncertainty in the assessments. Fuzzy sets were used to interpret uncertain information.

\section{Fuzzy sets}

To present uncertain values in the study, LR fuzzy numbers are used, which allow taking into account the uncertainty of experts as to the assessment. These numbers are represented by three parameters:

- parameter $\mathrm{m}$ is the actual value called the mean value, most likely or calculated according to the formula:

$m=\frac{m-\alpha+m+\beta}{2}$.

- the parameter $\alpha$ is a left dispersion (to the left of the parameter $\mathrm{m}$ ),

- the parameter $\beta$ is a right dispersion (to the right of parameter $m$ ).

In order to describe the function of affiliation of LR type number, the following formula was adopted:

$\boldsymbol{\mu}_{\boldsymbol{A}}(\boldsymbol{x})=\left\{\begin{array}{l}\boldsymbol{L}\left(\frac{\boldsymbol{m}-\boldsymbol{x}}{\boldsymbol{\alpha}}\right) \quad \text { where } \quad \boldsymbol{x}<\boldsymbol{m} \\ \mathbf{1} \text { where } \quad x=\boldsymbol{m} \\ \boldsymbol{R}\left(\frac{x-\boldsymbol{m}}{\boldsymbol{\beta}}\right) \quad \text { where } x>\boldsymbol{m}\end{array}\right.$.

The $\mathrm{L}$ and $\mathrm{R}$ functions are represented by a formula:

$L(x)=R(x)=\left\{\begin{array}{l}0 \quad \text { where } \quad x<m-\alpha \\ 1-|x| \quad \text { where } m-\alpha \leq x \leq m+\beta \\ 0 \quad \text { where } x>m+\beta\end{array}\right.$.

Assessments of rail lines determined by experts are presented as intervals $[m-\alpha, m]$ and $[m, m+\beta]$, which allows taking into account the uncertainty in regard of the value of the most unlikely $m$. Determinig an assessment of a rail line, mathematical operations on parameters $m$, $\alpha, \beta$ are conducted (Piegat, 1999). 


\section{Model for assessing the modernization of railway lines}

In the presented algorithm the analysis of railway lines from the finite set $\mathrm{M}$ of considered modernizations is assumed:

$M=\left\{M_{1}, M_{2}, \ldots, M_{i}, \ldots, M_{I}\right\}, \quad i=1, \ldots, I$,

based on a set of Level 1 criteria and a set of Level 2 criteria. The presented algorithm includes both quantitative and qualitative variables. In the case of qualitative criteria, the assessment of the modernization of railway lines is a point assessment, where the maximum number of points within a given criterion (sub-criterion) is determined. In order to enable a comparison of the values of different qualitative and quantitative criteria, assessment normalisation was applied.

The study also includes the possibility to assess the degree of trust in individual experts or investors. For this purpose, the variable $V_{e}$ is adopted, which specifies the validity of assessments of individuals assessing modernised lines:

$\sum_{e=1}^{E} V_{e}=1$.

It is assumed that the importance of the criteria are defined in the range [0,1], which is related to the condition that the sum of the criteria weights must be 1 .

a) The importance of Level 1 criteria is presented by the variable $W_{j}(j-$ Level 1 criterion). $\sum_{j=1}^{J} W_{j}=1$.

b) The importance of Level 2 criteria - subcriteria from individual target groups are presented in the form of a variable ( $\mathrm{j}$ - Level 1 criterion, $\mathrm{k}$ - Level 2 criterion).

$\sum_{k=1}^{K} W_{j k}=1$ 


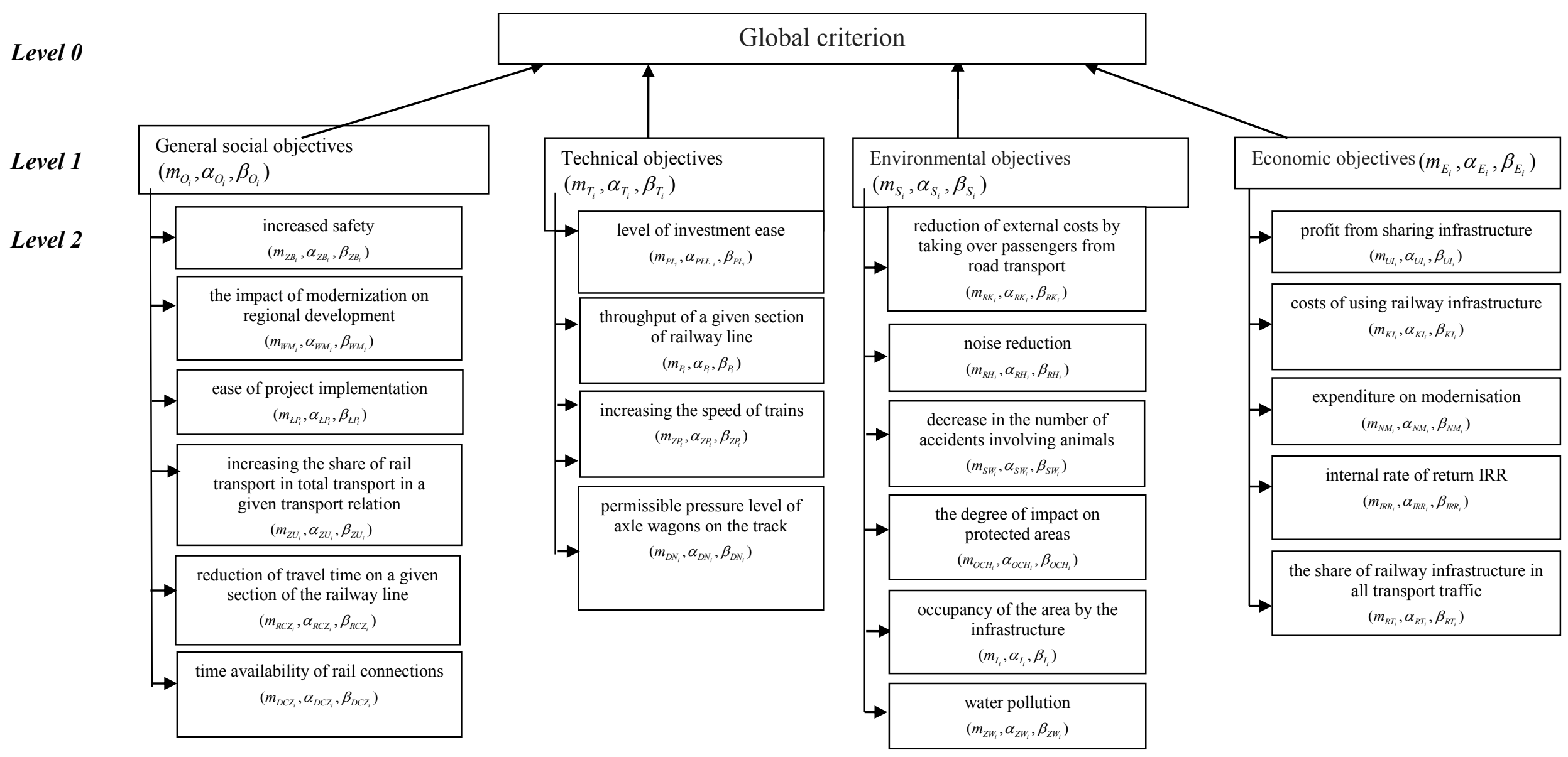

Figure 1. The structure of multi-criteria assessment of the modernisation of railway lines 
Since the assessment values of modernised railway lines are treated as the accomplished degree of an i-th railway line some ideal state within a given criterion, assessments should be standardized separately within each criterion of Level 2.

The normalisation of the criteria whose optimal values are the largest values is carried out according to the following formulas:

$\hat{\alpha}=\frac{\alpha}{\max (m+\beta)}$,

$\hat{m}=\frac{m}{\max (m+\beta)}$,

$\hat{\beta}=\frac{\beta}{\max (m+\beta)}$.

For the criteria that we expect the smallest value, we normalise according to the following formulas:

$$
\begin{aligned}
& \hat{\alpha}=1-\frac{\alpha}{\max (m+\beta)}, \\
& \hat{m}=1-\frac{m}{\max (m+\beta)}, \\
& \hat{\beta}=1-\frac{\beta}{\max (m+\beta)} .
\end{aligned}
$$

After the normalisation, the variables $\hat{\alpha}, \hat{m}$ i $\hat{\beta}$ are the new effective variables $m, \alpha, \beta$.

Based on specific fuzzy variables presented in Fig. 1, the total assessment of modernised railway lines according to individual Level 2 criteria is determined, described by three parameters $m, \alpha, \beta$ :

a) Social objectives

$$
\begin{aligned}
& m_{O_{e i}}=W_{11} \cdot m_{Z B_{e i}}+W_{12} \cdot m_{W M_{e i}}+W_{13} \cdot m_{E P_{e i}}+W_{14} \cdot m_{Z U_{e i}}+W_{15} \cdot m_{R C Z_{e i}}+W_{16} \cdot m_{D C Z_{e i}} \\
& \alpha_{O_{e i}}=W_{11} \cdot \alpha_{Z B_{e i}}+W_{12} \cdot \alpha_{W M_{e i}}+W_{13} \cdot \alpha_{E P_{e i}}+W_{14} \cdot \alpha_{Z U_{e i}}+W_{15} \cdot \alpha_{R C Z_{e i}}+W_{16} \cdot \alpha_{D C Z_{e i}} \\
& \beta_{O_{e i}}=W_{11} \cdot \beta_{Z B_{e i}}+W_{12} \cdot \beta_{W M_{e i}}+W_{13} \cdot \beta_{E P_{e i}}+W_{14} \cdot \beta_{Z U_{e i}}+W_{15} \cdot \beta_{R C Z_{e i}}+W_{16} \cdot \beta_{D C Z_{e i}}
\end{aligned}
$$

b) Technical objectives

$$
\begin{aligned}
& m_{T_{e i}}=W_{21} \cdot m_{P E_{e i}}+W_{22} \cdot m_{P_{e i}}+W_{23} \cdot m_{Z P_{e i}}+W_{24} \cdot m_{D N_{e i}} \\
& \alpha_{T_{e i}}=W_{21} \cdot \alpha_{P E_{e i}}+W_{22} \cdot \alpha_{P_{e i}}+W_{23} \cdot \alpha_{Z P_{e i}}+W_{24} \cdot \alpha_{D N_{e i}} \\
& \beta_{T_{e i}}=W_{21} \cdot \beta_{P E_{e i}}+W_{22} \cdot \beta_{P_{e i}}+W_{23} \cdot \beta_{Z P_{e i}}+W_{24} \cdot \beta_{D N_{e i}}
\end{aligned}
$$


c) Environmental objectives

$$
\begin{aligned}
& m_{S_{e i}}=W_{31} \cdot m_{R K_{e i}}+W_{32} \cdot m_{R H_{e i}}+W_{33} \cdot m_{S W_{e i}}+W_{34} \cdot m_{O C H_{e i}} \\
& \alpha_{S_{e i}}=W_{31} \cdot \alpha_{R K_{e i}}+W_{32} \cdot \alpha_{R H_{e i}}+W_{33} \cdot \alpha_{S W_{e i}}+W_{34} \cdot \alpha_{O C H_{e i}} \\
& \beta_{S_{e i}}=W_{31} \cdot \beta_{R K_{e i}}+W_{32} \cdot \beta_{R H_{e i}}+W_{33} \cdot \beta_{S W_{e i}}+W_{34} \cdot \beta_{O C H_{e i}}
\end{aligned}
$$

d) Economic objectives

$$
\begin{aligned}
& m_{E_{e i}}=W_{41} \cdot m_{U I_{e i}}+W_{42} \cdot m_{K I_{e i}}+W_{43} \cdot m_{N M_{e i}}+W_{44} \cdot m_{I R R_{e i}}+W_{45} \cdot m_{R T_{e i}} \\
& \alpha_{E_{e i}}=W_{41} \cdot \alpha_{U I_{e i}}+W_{42} \cdot \alpha_{K I_{e i}}+W_{43} \cdot \alpha_{N M_{e i}}+W_{44} \cdot \alpha_{I R R_{e i}}+W_{45} \cdot \alpha_{R T_{e i}} \\
& \beta_{E_{e i}}=W_{41} \cdot \beta_{U U_{e i}}+W_{42} \cdot \beta_{K I_{e i}}+W_{43} \cdot \beta_{N M_{e i}}+W_{44} \cdot \beta_{I R R_{e i}}+W_{45} \cdot \beta_{R T_{e i}}
\end{aligned}
$$

Next, normalisation is carried out again in accordance with formulas (8)-(13). Based on the cumulative assessments presented above, the final assessment of the modernised railway lines can be further determined as three parameters:

$$
\begin{aligned}
& m_{O L K_{e i}}=W_{1} \cdot m_{O_{e i}}+W_{2} \cdot m_{T_{e i}}+W_{3} \cdot m_{S_{e i}}+W_{4} \cdot m_{E_{i e}} \\
& \alpha_{O L K_{e i}}=W_{1} \cdot \alpha_{O_{e i}}+W_{2} \cdot \alpha_{T_{e i}}+W_{3} \cdot \alpha_{S_{e i}}+W_{4} \cdot \alpha_{E_{e i}} \\
& \beta_{O L K_{e i}}=W_{1} \cdot \beta_{O_{i}}+W_{2} \cdot \beta_{T_{i}}+W_{3} \cdot \beta_{S_{i}}+W_{4} \cdot \beta_{E_{i}}
\end{aligned}
$$

The resulting assessment of railway lines is fuzzy. To determine the actual value of the modernised lines, defuzzification should be carried out, assigning the real value $\mathrm{R} \_\mathrm{O}_{\mathrm{ei}}$ to OLK $_{\text {ei }}$ 's fuzzy number:

$$
R_{-} O_{e i}=\frac{3 \cdot m_{R_{-} O_{e i}}-\alpha_{R_{-} O_{e i}}+\beta_{R_{-} O_{e i}}}{3} .
$$

The above total assessment of modernised railway lines is an assessment obtained based on detailed assessments of the e-th person assessing modernised lines. To determine the final assessment of $\mathrm{O}_{\mathrm{i}}$ of individual railway lines, we use the formula:

$$
O_{i}=\frac{\sum_{e=1}^{E} V_{e} \cdot R_{-} O_{e i}}{\sum_{e=1}^{E} V_{e}} .
$$

In the presented algorithm the maximum value of an assessment in regard to Level 0 is sought, this assessment indicates the optimal investment in the modernisation of railway lines: $O_{i} \rightarrow M A X$ 


\section{Summary}

Investment projects in the modernisation of railway lines are an essential aspect. They create new travel opportunities while raising their standard (higher speeds mean shorter trips), favour access to the labour market, education and recreation. Moreover, they improve conditions of the transport of goods (better development of economic relations, easier transport of goods). This article was written as a response to the demand for the method of supporting such investments. The multicriterial fuzzy model proposed in the study may be a useful tool when choosing the optimal variant of railway line modernisation. Due to the selection of criteria, this model enables the assessment of railway lines from the point of view of various stakeholders and, by taking into account the importance of assessments set by investors or experts, it guarantees participation in the evaluation of individuals (institutions).

\section{References}

1. Jacyna, M., Wasiak, M. (2008). Zastosowanie wielokryterialnej oceny do wyboru wariantu modernizacji elementów infrastruktury kolejowej. Politechnika Warszawska.

2. Jacyna, M. (2001). Modelowanie wielokryterialne w zastosowaniu do systemów transportowych. Prace Naukowe Politechniki Warszawskiej, Transport, z. 47. Warszawa: Oficyna Wydawnicza.

3. Kacprzyk, J. (2001). Wieloetapowe sterowanie rozmyte. Warszawa: WNT.

4. Kacprzyk, J. (1986). Zbiory rozmyte w analizie systemowej. Warszawa: PWN.

5. Kukulski, J. (2016). Badania symulacyjne $i$ doświadczalne elementów taboru $i$ infrastruktury kolejowej $w$ aspekcie bezpieczeństwa i eksploatacji. Warszawa: Oficyna Wydawnicza Politechniki Warszawskiej,

6. Matusik, W. (2017). Koncepcja wielokryterialnej metody oceny systemu prowadzenia pociągów na modernizowanych liniach kolejowych. Badania, 7-8.

7. Piegat, A. (1999). Modelowanie i sterowanie rozmyte. Warszawa: AOW Exit.

8. Nyszk, W., Szeląg, K., Tymińska, I. (eds.) (2007). Aspekty logistyczne wykorzystania infrastruktury kolejowej. Warszawa: Akademia Obrony Narodowej.

9. Rosik, P., Kowalczyk, K. (2015). Rozwój infrastruktury drogowej i kolejowej a przesuniecie modalne $w$ Polsce $w$ latach 2000-2010, Warszawa: PAN IG i PZ.

10. Taylor, Z. (2007). Rozwój i regres sieci kolejowej w Polsce. Warszawa: PAN IG i PZ.

11. Towpik, K. (2012). Koleje dużych prędkości. Infrastruktura drogi kolejowej. Warszawa: Oficyna Wydawnicza Politechniki Warszawskiej.

12. Wolfenburg, A. (2011). Optymalne kierowanie ruchem pociagów w obszarze sieci kolejowej. Gorzów Wielkopolski: Wydawnictwo Państwowej Wyższej Szkoły Zawodowej. 